\title{
Spark Plasma Sintering of SiAlON Ceramics Synthesized via Various Cations Charge Stabilizers and Their Effect on Thermal and Mechanical Characteristics
}

\author{
Muhammad Zulqarnain Falak ${ }^{1}$, Bilal Anjum Ahmed ${ }^{1, *}$, Hasan Aftab Saeed ${ }^{1} \mathbb{D}$, Sajid Ullah Butt ${ }^{1} \mathbb{D}$, \\ Abbas Saeed Hakeem ${ }^{2}\left(\mathbb{D}\right.$ and Usman Ali Akbar ${ }^{3}$ \\ 1 Department of Mechanical Engineering, National University of Sciences and Technology, \\ Islamabad 44000, Pakistan; Muhammad.falak18@me.ceme.edu.pk (M.Z.F.); \\ hasan.saeed@ceme.nust.edu.pk (H.A.S.); sajidullahbutt@ceme.nust.edu.pk (S.U.B.) \\ 2 Interdisciplinary Research Center for Hydrogen \& Energy Storage (IRC-HES), \\ King Fahd University of Petroleum \& Minerals, Dhahran 31261, Saudi Arabia; ashakeem@kfupm.edu.sa \\ 3 Department of Mechanical Engineering, King Fahd University of Petroleum \& Minerals, \\ Dhahran 31261, Saudi Arabia; g201708430@kfupm.edu.sa \\ * Correspondence: bilal.anjum@ceme.nust.edu.pk
}

Citation: Falak, M.Z.; Ahmed, B.A.; Saeed, H.A.; Butt, S.U.; Hakeem, A.S. Akbar, U.A. Spark Plasma Sintering of SiAlON Ceramics Synthesized via Various Cations Charge Stabilizers and Their Effect on Thermal and Mechanical Characteristics. Crystals 2021, 11, 1378. https://doi.org/ $10.3390 /$ cryst11111378

Received: 23 October 2021

Accepted: 8 November 2021

Published: 12 November 2021

Publisher's Note: MDPI stays neutral with regard to jurisdictional claims in published maps and institutional affiliations.

Copyright: (C) 2021 by the authors Licensee MDPI, Basel, Switzerland. This article is an open access article distributed under the terms and conditions of the Creative Commons Attribution (CC BY) license (https:// creativecommons.org/licenses/by/ $4.0 /)$.

\begin{abstract}
Oxygen-rich SiAlON ceramics doped with various nanosized metal oxide (MO) stabilizers were synthesized with a view to examine their effect on thermal and mechanical characteristics. The nanosized starting powder precursors comprising $\mathrm{Si}_{3} \mathrm{~N}_{4}, \mathrm{AlN}, \mathrm{Al}_{2} \mathrm{O}_{3}$, and $\mathrm{SiO}_{2}$ along with oxides of $\mathrm{Ba}, \mathrm{Y}, \mathrm{Mg}, \mathrm{La}, \mathrm{Nd}, \mathrm{Eu}, \mathrm{Dy}, \mathrm{Er}$, and $\mathrm{Yb}$ as the $\mathrm{MO}$ charge stabilizer were employed in developing different SiAlON samples. Ultrasonic probe sonication was utilized to develop a homogenous mixture of initial powder precursors followed by spark plasma sintering (SPS) of the samples at the low temperature of $1500{ }^{\circ} \mathrm{C}$ coupled with $30 \mathrm{~min}$ of isothermal treatment. Sample compositions (according to general formula of alpha SiAlON: $\mathrm{M}_{\mathrm{m} / \mathrm{v}}{ }^{\mathrm{v}} \mathrm{Si}_{12-(\mathrm{m}+\mathrm{n})} \mathrm{Al}_{\mathrm{m}+\mathrm{n}} \mathrm{O}_{\mathrm{n}} \mathrm{N}_{16-\mathrm{n}}$ ) selected in the present study are represented by $\mathrm{m}$ value of 1.1 and $\mathrm{n}$ value of 1.6. The synthesized samples were evaluated for their physical behavior, microstructural and crystal structure evolution, and thermal and mechanical characteristics. More specifically, the sintered ceramics were examined by X-ray diffraction and electron microscopy to comprehend and relate the structural characteristics with the densification, thermal conductivity, hardness, and fracture toughness. The high reactivity of the nanopowders and the localized heating provided by SPS resulted in densified ceramics with relative densities in the range of $92-96 \%$. Vickers hardness values were found to be in the range of 12.4-17.0 GPa and were seen to be profoundly influenced by the grain size of the alpha SiAlON (primary) phase. The fracture toughness of the samples was measured to be in the range of 4.1-6.2 MPa. $\mathrm{m}^{1 / 2}$. SiAlON samples synthesized using $\mathrm{Er}$ and $\mathrm{Yb}$ charge stabilizers were found to have the highest fracture toughness of 5.7 and $6.2 \mathrm{MPa} \cdot \mathrm{m}^{1 / 2}$, primarily due to the relatively higher content of the elongated beta phase. While there was no obvious relationship between the thermal conductivity and the alpha SiAlON metal charge stabilizers, the values were seen to be influenced by the grain size of alpha phase where Dy-SiAlON had the lowest thermal conductivity of $5.79 \mathrm{~W} / \mathrm{m} \cdot \mathrm{K}$ and Er-SiAlON showed the highest value of thermal conductivity $(6.91 \mathrm{~W} / \mathrm{m} \cdot \mathrm{K})$. It was concluded that scientifically selected metal oxide charge stabilizers are beneficial in developing SiAlON ceramics with properties tailored according to specific applications.
\end{abstract}

Keywords: SiAlONs; spark plasma sintering; thermal and mechanical behavior; rare earth; alkaline earth

\section{Introduction}

Ceramic materials are extensively employed in industrial applications due to their exceptional wear resistance, stability at elevated temperatures, hardness, and stable physical and chemical properties. Alternately, these ceramics have a highly brittle nature and 
low fracture toughness, which imposes a severe limitation on their use in many engineering applications [1-3]. Manufacturing of products such as cutting tools, turbine blades, and bearings require materials that provide sufficiently good toughness, hardness, high strength, and exceptional resistance to erosion and corrosion. Silicon nitride $\left(\mathrm{Si}_{3} \mathrm{~N}_{4}\right)$ is one of the ceramics having excellent hardness and strength while providing high chemical resistance and low density [4-8]. The key to achieving desirable mechanical, physical, and chemical properties is to have fully densified silicon nitride ceramics. The most common challenge in preparing well-densified silicon nitride ceramics is that of restricted diffusion in these materials owing to the highly covalent nature of bonds. Therefore, near-complete densification of these materials requires elevated sintering temperatures, which gives rise to operational complexities. It is due to this reason that metal oxides and different types of additives have been used as synthesizing and densifying agents which help avoid a long duration of synthesis and high temperature complexities. These additions modify the structure of silicon nitride and lead to the creation of SiAlONs [9-13]. In SiAlONs, certain $\mathrm{N}$ and $\mathrm{Si}$ atoms are substituted by $\mathrm{O}$ and $\mathrm{Al}$ atoms and the charge neutrality is ensured by the incorporation of a metal cation $[3,8,9,14,15]$. $\alpha$-SiAlON and $\beta$-SiAlON phases have been frequently reported in literature. Elongated grain morphology in $\beta$-SiAlON is known to impart higher fracture toughness to the SiAlON ceramics $[6,14,16-19]$, while equiaxed morphology of $\alpha$-SiAlON is known for its high hardness $[6,17,20,21]$. It has been established that the formation of a eutectic liquid phase in SiAlONs acts as the synthesis aid to facilitate densification behavior of ceramic composites, such as the work reported on $\mathrm{SiAlON} / \mathrm{ZrB}_{2}-\mathrm{SiC}$ composites produced by SPS and hot pressing techniques [22,23]. Employment of SPS as a sintering route has also resulted in an active focus on controlling the grain growth and morphology of the phases evolved. SPS is a relatively new method used to consolidate starting powders by applying a combination of axial pressure and pulsed direct current to the materials placed within a die of graphite. This approach is sometimes also referred to as the field-assisted sintering technique [24]. Due to the short process time and fewer processing steps it requires, this approach is considered as an energy-saving technology $[25,26]$. The prominent characteristics of the SPS process include localized generation of plasma, focused plasma-material interaction, and uniform yet fast heating and cooling of the sample $[11,12,16,17,27-31]$. Synthesis of a variety of new ceramic materials such as WC-Co, $\mathrm{C}_{3} \mathrm{~N}_{4}-\mathrm{ZrB}_{2}-\mathrm{SiC}, \mathrm{TiC}-\mathrm{Si}_{3} \mathrm{~N}_{4}, \mathrm{TiC}-\mathrm{ZrN}-\mathrm{C}, \mathrm{TiB}_{2}-\mathrm{hBN}$, and $\mathrm{TiC}^{-} \mathrm{SiC}_{\mathrm{W}}-\mathrm{WC}_{\mathrm{n}}$ via SPS technology have been reported in literature [32-37]. Furthermore, synthesis of porous $\mathrm{Al}_{2} \mathrm{O}_{3}-\mathrm{CNT}$ membranes using SPS technology has also been reported in [38].

Various additives have been employed by researchers to achieve desirable physical, thermal, mechanical, and wear-resistant characteristics of SiAlON-based materials [13], [39-46]. Numerous synthesis techniques along with a range of temperatures have been employed to enhance the thermal shock resistance, toughness, hardness, and densification of SiAlON ceramics. Some studies on the synthesis of SiAlONs have been published that have adopted the conventional sintering route and have utilized a variety of rare earth (RE) and alkaline earth (AE) metal cations; however, very limited literature is available on the synthesis of rare earth- and alkaline-earth-doped SiAlONs via the non-conventional sintering technique [41,47-51]. Table 1 summarizes the findings of past research conducted on alkaline and rare-earth-doped SiAlON ceramics. Souza et al. reported the development of alpha-SiAlON/SiC composites through conventional sintering route at a temperature of $1750{ }^{\circ} \mathrm{C}$ [52]. With the addition of $\mathrm{SiC}$ reinforcement from $0-20 \mathrm{wt} . \%$, the hardness values were measured to be 12-18.9 GPa. The undesirably low hardness values at higher $\mathrm{SiC}$ concentrations were attributed to a reduction in relative density which decreases from $95.4 \%$ at $0 \mathrm{wt} . \%$ of $\mathrm{SiC}$ to $88.3 \%$ at $20 \mathrm{wt} . \%$ of $\mathrm{SiC}$. Such a drastic drop in relative density can be attributed to the decrease in the amount of additives with the increase in $\mathrm{SiC}$ reinforcement, thereby decreasing the eutectic liquid phase, which adversely affects hardness.

Cai et al. reported work on nitrogen rich Ca-SiAlONs while incorporating $\mathrm{CaH}_{2}$ as the source for metal cation, which resulted in the elongated morphology of $\alpha$-SiAlON [53]. 
Synthesis of Y/Ca doped $\alpha$-SiAlON was carried out by Yi et al. using the SPS technique at $1600{ }^{\circ} \mathrm{C}$ [54]. A transformation of an $\alpha$ to $\beta$ phase was reported for $Y-\alpha-S i A l O N$ in the range of $1400-1500{ }^{\circ} \mathrm{C}$. On the other hand, there was no apparent $\alpha$ to $\beta$ transition for $\mathrm{Ca}-\alpha-\mathrm{SiAlON}$ even at $1600^{\circ} \mathrm{C}$. Vickers hardness values of $19.95 \mathrm{GPa}$ (for Ca-SiAlON) and the $18.56 \mathrm{GPa}$ (for Y-SiAlON) were reported. Xiong et al. reported the development of transparent Mg-stabilized SiAlON ceramics using the SPS technique [55]. It was further explained that the densification and $\alpha / \beta$ phase ratio had a major influence on the mechanical and optical characteristics of Mg-SiAlONs. Maximum values for optical transmission, surface hardness, and fracture toughness were $66 \%, 21.4 \mathrm{GPa}$, and $6.1 \mathrm{MPa} \cdot \mathrm{m}^{1 / 2}$.

Jojo et al. synthesized Y-doped silicon nitride and aluminum nitride ceramics using the SPS technique, where $Y$ content was varied from 3-7 vol\% [56]. It was measured that a sample doped with $7 \mathrm{vol} \% \mathrm{Y}$ resulted in the best Vickers hardness and fracture toughness values both at $1600{ }^{\circ} \mathrm{C}$ and $1675^{\circ} \mathrm{C}$. Ye et al. used $5 \mathrm{wt} . \%$ barium aluminosilicate (BAS) as the sintering aid to synthesize $\mathrm{Y}-\alpha$-SiAlON at $1600^{\circ} \mathrm{C}$ to yield the maximum hardness of 19.2 GPa [57]. Similar results were published by Wang et al. [58]. $\mathrm{ZrB}_{2}-\mathrm{ZrC}-\mathrm{SiC}$ composites were developed by Akin and Goller at $1750{ }^{\circ} \mathrm{C}$ for isothermal holding time of $300 \mathrm{~s}$ by SPS. The results showed improvement in densification while the surface hardness was observed to decrease by increasing $\mathrm{ZrC}$ concentration. $\alpha$-SiAlON/ZrC and $\alpha-S i A l O N / \mathrm{TaC}$ composites were developed by Nino et al. at $1600{ }^{\circ} \mathrm{C}$ using the hot pressing technique [59]. At $1600{ }^{\circ} \mathrm{C}$, the $\beta$-SiAlON phase precipitated from the $\alpha$-SiAlON phase, resulting in improved Young's modulus.

Table 1. Results and literature review of different studies on SiAlONs of various alkaline earth and rare earth metal additives.

\begin{tabular}{|c|c|c|c|c|c|c|c|}
\hline S/No & Sample Name & Temperature $\left({ }^{\circ} \mathrm{C}\right)$ & Holding Time & $\begin{array}{l}\text { Pressure/Synthesis } \\
\text { Method }\end{array}$ & $\begin{array}{c}\mathrm{H}_{\mathrm{v}} \\
(\mathrm{GPa})\end{array}$ & $\begin{array}{c}\mathrm{K}_{\mathrm{IC}} \\
\left(\mathrm{MPa} \cdot \mathrm{m}^{1 / 2}\right)\end{array}$ & Ref \\
\hline 1 & Beta-SiAlON & ${ }^{*} \mathrm{NA}$ & ${ }^{*} \mathrm{NA}$ & ${ }^{*} \mathrm{NA}$ & 19.9 & 2.9 & [60] \\
\hline 2 & Alpha-SiAlON & *NA & *NA & *NA & 15.9 & 5.9 & {$[60]$} \\
\hline 3 & Ytterbium-alpha-SiAlON & 1500 & $30 \mathrm{~min}$ & $\begin{array}{l}\text { SPS } \\
50 \mathrm{MPa}\end{array}$ & 20.6 & 6.3 & {$[61]$} \\
\hline 4 & Calcium-alpha-SiAlON & 1750 & $60 \mathrm{~min}$ & $\begin{array}{l}\mathrm{HP} \\
20 \mathrm{MPa}\end{array}$ & 19.4 & 6.1 & {$[58]$} \\
\hline 5 & 50 wt. $\%$ TiN-alpha-SiAlON & 1600 & NA* & $\begin{array}{l}\text { SPS } \\
100 \mathrm{MPa}\end{array}$ & 15.7 & 7.9 & [25] \\
\hline 6 & 3 wt. $\%$ MgO-beta-SiAlON+ 7 wt. $\% \mathrm{Y}_{2} \mathrm{O}_{3}$ & 1750 & $150 \mathrm{~min}$ & $\begin{array}{l}\mathrm{HP} \\
30 \mathrm{MPa}\end{array}$ & 20.9 & 6.1 & {$[62]$} \\
\hline 7 & $\begin{array}{l}30 \mathrm{wt} \text { \% Silicon } \\
\text { carbide-calcium-Alpha-SiAlON }\end{array}$ & 1500 & $30 \mathrm{~min}$ & $\begin{array}{l}\text { SPS } \\
\text { MPa }\end{array}$ & 21.1 & 7.3 & [14] \\
\hline 8 & 5 wt.\% BAS-alpha-SiAlON & 1800 & $5 \mathrm{~min}$ & $\begin{array}{c}\text { SPS } \\
25 \mathrm{MPa}\end{array}$ & 19.2 & 6.8 & [57] \\
\hline 9 & Magnisium-alpha-SiAlON & 1850 & $60 \mathrm{~min}$ & $\begin{array}{l}\text { SPS } \\
30 \mathrm{MPa}\end{array}$ & 21.4 & 6.1 & [55] \\
\hline 10 & Calcium-magnisium-alpha-SiAlON & 1750 & $60 \mathrm{~min}$ & $\begin{array}{c}\mathrm{HP} \\
20 \mathrm{MPa}\end{array}$ & 19.7 & 5.8 & [58] \\
\hline 11 & Rare earth-Silicon carbide-beta-SiAION & 1950 & ${ }^{*} \mathrm{NA}$ & Cold pressed & 19.5 & 4.2 & [63] \\
\hline 12 & Calcium-alpha-SiAlON & 1400 & $10 \mathrm{~min}$ & $\begin{array}{c}\text { SPS } \\
40 \mathrm{MPa}\end{array}$ & 19.9 & - & {$[54]$} \\
\hline
\end{tabular}

${ }^{*}$ NA—not available.

Ahmed et al. reported the development of Ca- $\alpha$-SiAlON samples at $1500{ }^{\circ} \mathrm{C}$ using SPS [12]. The $\alpha /(\alpha+\beta)$ phase boundary was examined. Compositions with higher oxide content were shown to help produce the $\beta$-SiAlON phase, thereby enhancing the fracture toughness of the samples. The $\mathrm{Ca}-\alpha-\mathrm{SiAlON} / \mathrm{SiC}$ composites were prepared by Khan et al., utilizing the SPS process at $1500{ }^{\circ} \mathrm{C}$ with $30 \mathrm{~min}$ holding time. Fracture toughness of $7.3 \mathrm{MPa} \cdot \mathrm{m}^{1 / 2}$ and Vickers hardness of $21.1 \mathrm{GPa}$ was reported [14].

In the present work, various metal cations stabilized oxygen-rich SiAlONs are developed at a low synthesis temperature of $1500{ }^{\circ} \mathrm{C}$ by employing the SPS technique. Furthermore, the effect of these metal charge stabilizers on the microstructure, phase evolution, and physical and thermomechanical characteristics is analyzed. Ultrasonic probe sonication is employed to achieve a homogenous mixture of starting powder mixture. The influence of RE and AE MOs as additives is evaluated in an effort to improve the much desired thermal and mechanical behavior of SiAlONs. All precursors used are of a nano-scale size, 
which facilitates the synthesis at $1500{ }^{\circ} \mathrm{C}$. The metal oxide precursors used as the charge stabilizers include $\mathrm{BaO}, \mathrm{MgO}, \mathrm{Y}_{2} \mathrm{O}_{3}, \mathrm{La}_{2} \mathrm{O}_{3}, \mathrm{Nd}_{2} \mathrm{O}_{3}, \mathrm{Dy}_{2} \mathrm{O}_{2}, \mathrm{Er}_{2} \mathrm{O}_{3}, \mathrm{Yb}_{2} \mathrm{O}_{3}$, and $\mathrm{Eu}_{2} \mathrm{O}_{3}$.

\section{Materials and Methods}

In the preparation of SiAlON samples, the powder blend of the initial precursors was reacted together. SiAlON samples were synthesized with commercially procured materials $\mathrm{SiO}_{2}(\sim 50 \mathrm{~nm}$, Sigma-Aldrich, St. Louis, MO, USA), AlN (less than $100 \mathrm{~nm}$, USA, Sigma-Aldrich, St. Louis, MO, USA) and $\mathrm{Si}_{3} \mathrm{~N}_{4}(\sim 300$ to $500 \mathrm{~nm}$, UBE Industries, SN-E10, Tokyo, Japan). Metal oxides procured from USA, Sigma-Aldrich, included BaO, with purity over 99 percent, while the remainder of the pure oxides having a purity of greater than 99 percent were purchased from Champur, Germany. Table 2 enlists the weight percent of each powder precursor used to prepare the respective SiAlONs. The general formula utilized for the synthesis of SiAlONs is $\mathrm{M}_{(\mathrm{m} / \mathrm{v})}{ }^{\mathrm{v}} \mathrm{Si}_{12-(\mathrm{m}+\mathrm{n})} \mathrm{Al}_{(\mathrm{m}+\mathrm{n})} \mathrm{O}_{\mathrm{n}} \mathrm{N}_{16-n}$, where $\mathrm{M}$ represents the metal cation. The variables $\mathrm{n}$ and $\mathrm{m}$ indicate $\mathrm{Al}-\mathrm{O}$ and $\mathrm{Al}-\mathrm{N}$ bonds, respectively. In the general formula $\mathrm{n}+\mathrm{m}$ : $\mathrm{Si}-\mathrm{N}$ bonds are replaced by $\mathrm{m}(\mathrm{Al}-\mathrm{O})$ bonds, while $\mathrm{v}$ represents the valency of metal cation $\mathrm{M}$ (which is +3 for all the metal cations except for $\mathrm{Ba}$ and $\mathrm{Mg}$, for which it is +2 ). In this study, the composition represented by $m=1.1$ and $n=1.6$ was selected for the synthesis. VCX 750 probe sonicator was used to homogenize the powder mixture in the ethanol medium for up to $20 \mathrm{~min}$. Probe-sonicated powder mixture was then dried at $90{ }^{\circ} \mathrm{C}$ for a period of $24 \mathrm{~h}$ in an oven. The dried powder mixture of initial powder precursors was sintered using FCT Systeme, HP D5 SPS machine. Uniaxial compression pressure of $50 \mathrm{MPa}$ was maintained constant throughout the process for the powder mixture enclosed in a $20 \mathrm{~mm}$ graphite die $[11-14,26,64]$. The maximum sintering temperature of $1500{ }^{\circ} \mathrm{C}$ was employed whereas the holding time of 30 min was used at the maximum temperature for all the samples [13,42]. A high heating rate of $100{ }^{\circ} \mathrm{C}$ per minute and a constant vacuum of $5 \times 10^{-2}$ mbar was maintained for the samples. SPS densification curves for the selected samples highlighting the major densification stages are shown in Figure 1. The temperature corresponding to the initiation of various stages are illustrated as an inset in Figure 1. Sintered samples were ground off using SiC abrasive grinding papers to remove the graphite layer and were subsequently grounded and polished using diamond disks and a diamond polishing medium.

Table 2. Starting chemical compositions of SiAlON ceramics along with the weight percent of respective powder precursors employed in the synthesis.

\begin{tabular}{|c|c|c|c|c|c|c|c|c|c|c|}
\hline Sample No & Chemical Formula & $\begin{array}{l}\text { Charge } \\
\text { Stabilizer }\end{array}$ & $\begin{array}{c}\text { Metal } \\
\text { Oxide (MO) }\end{array}$ & $\begin{array}{l}\text { Melting Temp } \\
\text { of MO }\left({ }^{\circ} \mathrm{C}\right)\end{array}$ & $\underset{(\mathrm{nm})}{\text { MO Size }}$ & $\begin{array}{l}\mathrm{Si}_{3} \mathrm{~N}_{4} \\
\text { (wt.\%) }\end{array}$ & $\begin{array}{c}\text { AlN } \\
\text { (wt. \%) }\end{array}$ & $\begin{array}{c}\text { MO } \\
\text { (wt.\%) }\end{array}$ & $\begin{array}{c}\mathrm{SiO}_{2} \\
\text { (wt.\%) }\end{array}$ & $\begin{array}{l}\mathrm{Al}_{2} \mathrm{O}_{3} \\
\text { (wt.\%) }\end{array}$ \\
\hline 1 & $\mathrm{Mg}_{0.55} \mathrm{Si}_{9.3} \mathrm{Al}_{2.7} \mathrm{O}_{1.6} \mathrm{~N}_{14.4}$ & $\mathrm{Mg}$ & $\mathrm{MgO}$ & 2852 & 50 & 3.86 & 73.92 & 16.29 & 3.73 & 2.20 \\
\hline 2 & $\mathrm{Ba}_{0.55} \mathrm{Si}_{9.3} \mathrm{Al}_{2.7} \mathrm{O}_{1.6} \mathrm{~N}_{14.4}$ & $\mathrm{Ba}$ & $\mathrm{BaO}$ & 1923 & 200 & 13.26 & 66.70 & 14.70 & 3.37 & 1.98 \\
\hline 3 & $\mathrm{Y}_{0.367} \mathrm{Si}_{9.3} \mathrm{Al}_{2.7} \mathrm{O}_{1.6} \mathrm{~N}_{14.4}$ & $\mathrm{Y}$ & $\mathrm{Y}_{2} \mathrm{O}_{3}$ & 2425 & 50 & 6.98 & 71.52 & 15.76 & 3.61 & 2.12 \\
\hline 4 & $\mathrm{La}_{0.367} \mathrm{Si}_{9.3} \mathrm{Al}_{2.7} \mathrm{O}_{1.6} \mathrm{~N}_{14.4}$ & $\mathrm{La}$ & $\mathrm{La}_{2} \mathrm{O}_{3}$ & 2315 & 30 & 9.77 & 69.38 & 15.29 & 3.50 & 2.06 \\
\hline 5 & $\mathrm{Nd}_{0.367} \mathrm{Si}_{9.3} \mathrm{Al}_{2.7} \mathrm{O}_{1.6} \mathrm{~N}_{14.4}$ & $\mathrm{Nd}$ & $\mathrm{Nd}_{2} \mathrm{O}_{3}$ & 2233 & 80 & 10.09 & 69.38 & 15.29 & 3.50 & 2.06 \\
\hline 6 & $\mathrm{Eu}_{0.367} \mathrm{Si}_{9.3} \mathrm{Al}_{2.7} \mathrm{O}_{1.6} \mathrm{~N}_{14.4}$ & $\mathrm{Eu}$ & $\mathrm{Eu}_{2} \mathrm{O}_{3}$ & 2350 & 60 & 10.55 & 69.38 & 15.29 & 3.50 & 2.06 \\
\hline 7 & $\mathrm{Dy}_{0.367} \mathrm{Si}_{9.3} \mathrm{Al}_{2.7} \mathrm{O}_{1.6} \mathrm{~N}_{14.4}$ & Dy & $\mathrm{Dy}_{2} \mathrm{O}_{3}$ & 2408 & 55 & 11.18 & 69.38 & 15.29 & 3.50 & 2.06 \\
\hline 8 & $\mathrm{Er}_{0.367} \mathrm{Si}_{9.3} \mathrm{Al}_{2.7} \mathrm{O}_{1.6} \mathrm{~N}_{14.4}$ & Er & $\mathrm{Er}_{2} \mathrm{O}_{3}$ & 2344 & 40 & 11.47 & 69.38 & 15.29 & 3.50 & 2.06 \\
\hline 9 & $\mathrm{Yb}_{0.367} \mathrm{Si}_{9.3} \mathrm{Al}_{2.7} \mathrm{O}_{1.6} \mathrm{~N}_{14.4}$ & $\mathrm{Yb}$ & $\mathrm{Yb}_{2} \mathrm{O}_{3}$ & 2355 & 100 & 11.82 & 69.38 & 15.29 & 3.50 & 2.06 \\
\hline
\end{tabular}




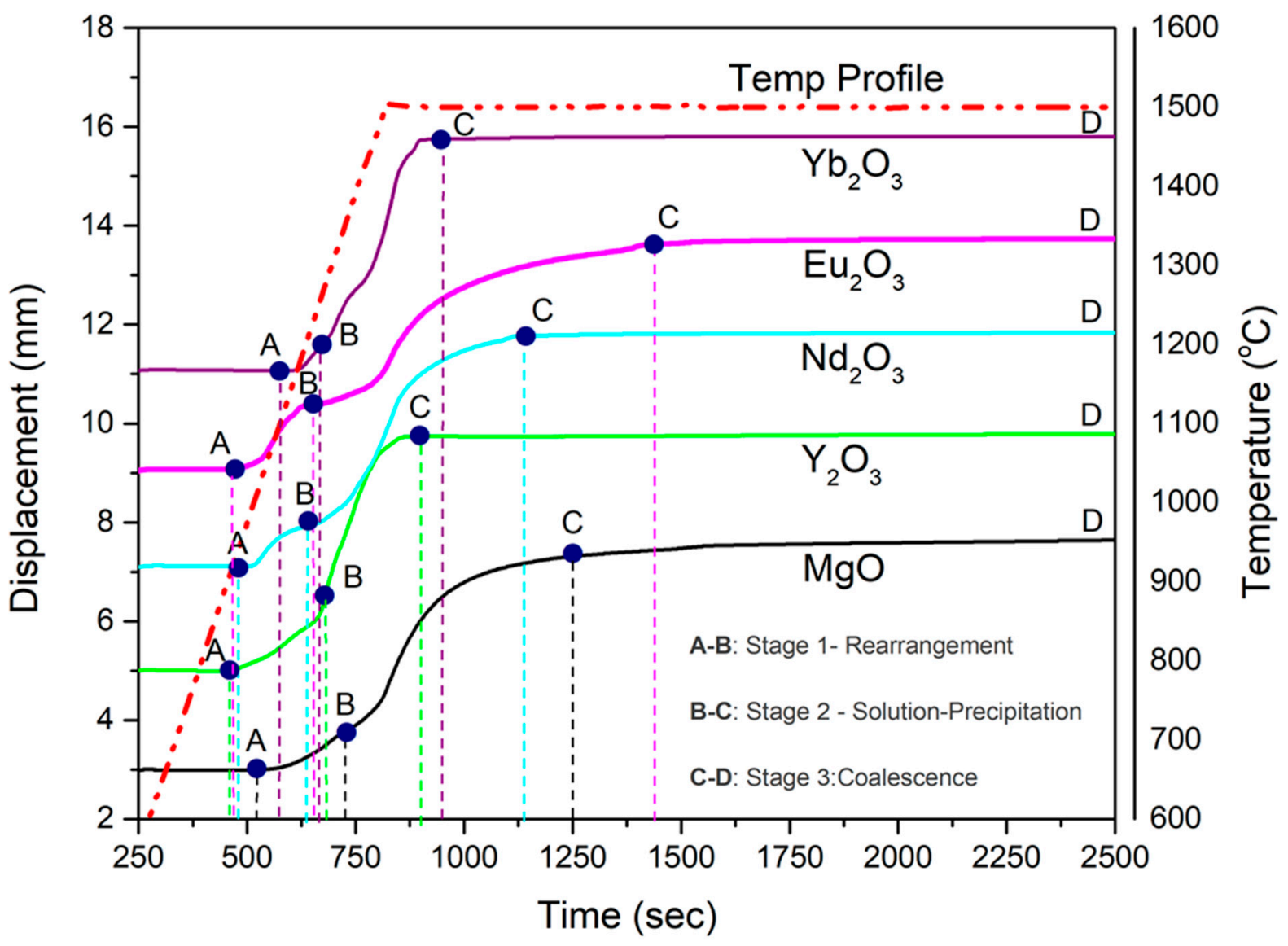

\begin{tabular}{llllll}
\hline & \multicolumn{5}{c}{ Temperature $\left({ }^{\circ} \mathrm{C}\right)$} \\
\cline { 2 - 6 } & $\mathbf{M g O}$ & $\mathbf{Y}_{2} \mathbf{O}_{3}$ & $\mathbf{N d}_{2} \mathbf{O}_{3}$ & $\mathrm{Eu}_{2} \mathbf{O}_{3}$ & $\mathbf{Y b}_{2} \mathbf{O}_{3}$ \\
\hline A & 1022 & 919 & 956 & 932 & 1109 \\
B & 1357 & 1270 & 1185 & 1210 & 1226 \\
C & 1500 & 1497 & 1500 & 1498 & 1496 \\
D & 1500 & 1500 & 1500 & 1500 & 1500 \\
\hline
\end{tabular}

Figure 1. Spark plasma sintered densification behavior of synthesized ceramics.

The fractured surface morphology of the sintered samples was examined using a field emission scanning electron microscope (Lyra3, FESEM, Czech Republic, Tescan) in the backscattered mode. It was equipped with the dispersive energy $X$-ray spectrometer to monitor the elemental distribution. Phase analysis was performed using Miniflex powder $X$-ray diffractometer where $\mathrm{Cu}$ source having a wavelength of $0.15416 \mathrm{~nm}, 10 \mathrm{~mA}$ current, and $30 \mathrm{kV}$ voltage were set as the equipment parameters. Archimedean principle was employed for measuring the density of the sintered samples. In order to calculate the density values, a density balance kit (Xing Yun, Model \# 2019129071) was used with deionized water as the sample immersion medium. The density of the samples was calculated on average by five measurements. Theoretical densities of the samples were calculated using the weight percent of the initial precursors in a sample (see Table 2) and the rule of mixtures. To evaluate the Vickers hardness of SiAlON samples, a $10 \mathrm{~kg}(98.06 \mathrm{~N})$ load was applied by means of a universal hardness test ZwickRoell, ZHU250. Evan's equation (Equation (1)) was used to measure the fracture toughness $\left(\mathrm{K}_{\mathrm{Ic}}\right)$ of the samples. In this equation, ' $H$ ' represents Vickers hardness, ' $a$ ' represents half of the average diagonal length 
(microns) and ' $c$ ' is the average length of the cracks (microns) [65]. C-Therm, TCi, Canada was used to evaluate the thermal conductivity of the specimens at room temperature.

$$
\mathrm{K}_{\mathrm{IC}}=0.16\left(\frac{c}{a}\right)^{-1.5}\left(H a^{0.5}\right)
$$

SPS densification curves of selected samples highlighting various stages of synthesis process are shown in Figure 1. Though the generic densification behavior of all the samples was similar, the solution-diffusion-precipitation stage was seen to be influenced by the melting temperature of the metal oxide precursors. In the case of $\mathrm{MgO}$ having the highest melting temperature of $2852{ }^{\circ} \mathrm{C}$, the solution-precipitation state started at around $1357{ }^{\circ} \mathrm{C}$. In contrast, for $\mathrm{Nd}_{2} \mathrm{O}_{3}$ (having the lowest melting temperature), the solution-precipitation stage started at around $1185^{\circ} \mathrm{C}$. Furthermore, despite the difference observed in the onset temperature of various stages, the initiation of the final coalescence stage remained the same for all the samples. A similar observation was reported by Hakeem et al. in their study on the densification behavior of alpha SiAlON ceramics [61].

\section{Results and Discussion}

\subsection{Phase Evolution and Microstructure Analysis}

In this work, commercially available powders were procured. Chemical compositions of the SiAlON samples, along with the respective weight percent of the starting powders and their characteristics are expressed in Table 2. Nine samples were synthesized using metal oxides, namely: $\mathrm{La}_{2} \mathrm{O}_{3}, \mathrm{Nd}_{2} \mathrm{O}_{3}, \mathrm{Eu}_{2} \mathrm{O}_{3}, \mathrm{Dy}_{2} \mathrm{O}_{3}, \mathrm{Er}_{2} \mathrm{O}_{3}, \mathrm{Yb}_{2} \mathrm{O}_{3}, \mathrm{MgO}, \mathrm{BaO}$, and $\mathrm{Y}_{2} \mathrm{O}_{3}$. As shown in the densification plot of spark plasma sintered samples (Figure 1), the evolution of SiAlON phases was observed to take place in the range of $\sim 1000-1500{ }^{\circ} \mathrm{C}$. The solution-precipitation process initiated at around $\sim 1200{ }^{\circ} \mathrm{C}$ and continued until almost $1500{ }^{\circ} \mathrm{C}$. Similar observation has been reported in previous studies $[13,19,28,66]$. It is believed that the nitride powders reacted with the oxide precursors to form the oxynitride eutectic liquid phase, which facilitated the densification of SiAlON ceramic. The amount of the eutectic liquid increased with the rise in temperature and complete conversion into SiAlON was achieved at $1500{ }^{\circ} \mathrm{C}$.

Additionally, the present study was aimed at determining the effect of alkaline and rare earth stabilizing cations on phase formation, microstructure evolution, and thermal and mechanical properties of SiAlON samples. The XRD patterns of the synthesized samples labelled with the corresponding phases are depicted in Figure 2. Alpha SiAlON (ICD\# 00-042-0252) phase was seen to be present in all the samples as the major phase, along with beta SiAlON (ICD\# 00-048-1615) as the minor phase. The presence of a major alpha phase coupled with a minor beta phase in all the samples confirms the fact that the initial composition selected for this study belongs to the oxygen-rich alpha/beta region and that the replacement of cations did not have any significant effect on the single-phase alpha stability regime. Nevertheless, it was seen that the cationic size of the stabilizing cations did influence the XRD peak intensities and the peak positions. For instance, with the change in rare earth cationic size (La $(250 \mathrm{pm})$ having clear discrete cationic size as compared to $\mathrm{Nd}(229 \mathrm{pm}))$ the alpha reflexes shifted to a slightly lower 2-theta value, indicating higher accommodation of stabilizing cation within the alpha unit cell. Furthermore, AlN polytype (ICD\# 00-042-0161 and ICD\# 00-042-0160) reflexes were also observed in some of the samples, as was reported in previous studies as well [61]. Other than this, a few additional reflexes were observed in the sample synthesized using $\mathrm{BaO}$. The additional reflexes were identified as $\mathrm{Ba}_{2} \mathrm{Si}_{10} \mathrm{Al}_{2} \mathrm{O}_{4} \mathrm{~N}_{14}$ (ICDD\# 00-057-0526) phase [61]. BaO having the lowest melting temperature of $1923^{\circ} \mathrm{C}$ resulted in the formation of the additional phase. A similar observation was reported by Hakeem et al. [61]. 


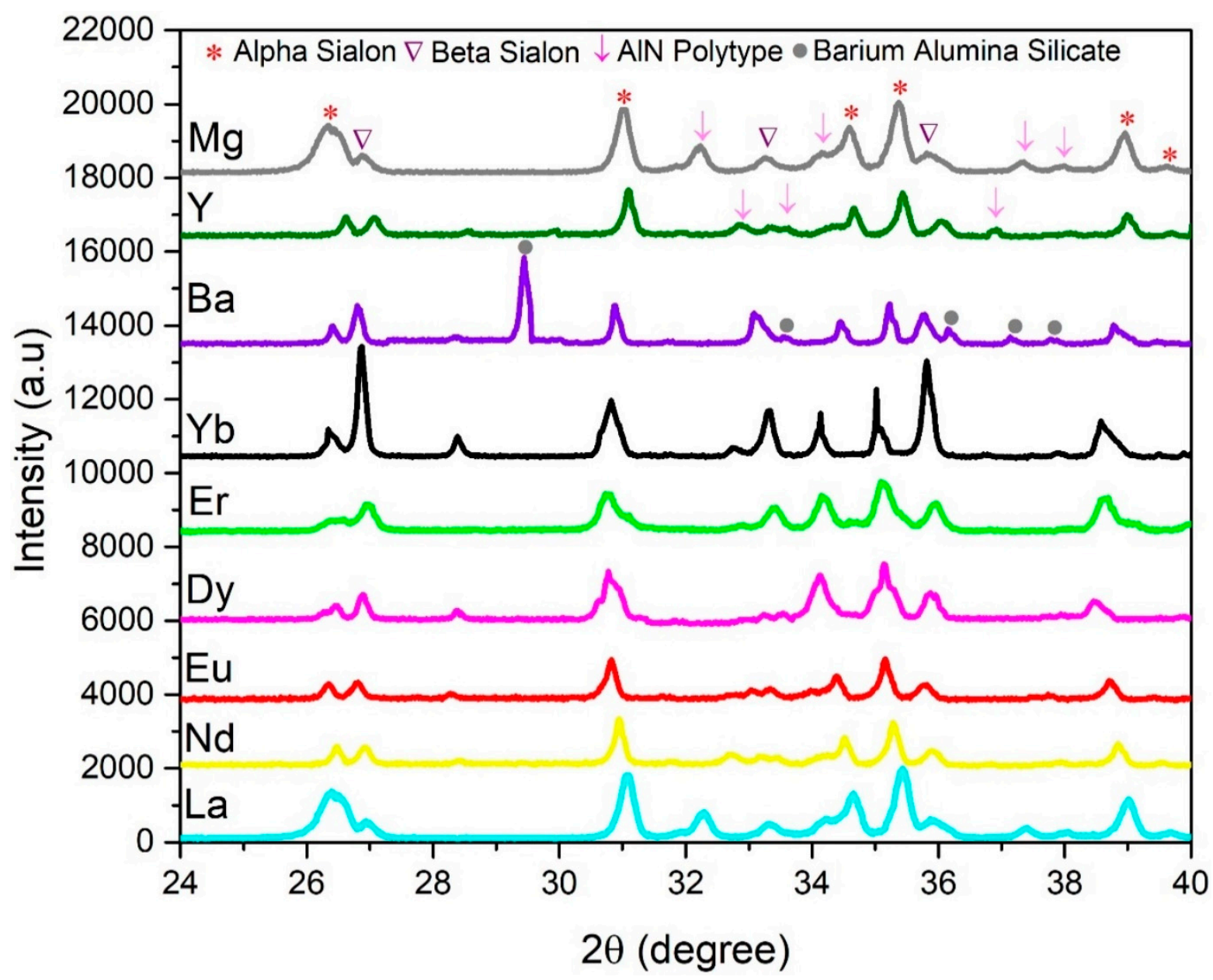

Figure 2. XRD patterns of various synthesized SiAlONs using alkaline earth and rare earth metal cations.

Figure 3 depicts the low magnification fractured surface morphology of SiAlON doped with various cations, all sintered at $1500^{\circ} \mathrm{C}$. As was also observed in the X-ray diffraction plot, the fracture surface of La stabilized SiAlON (Figure 3a) does not show any visible signs of the glassy phase. Highlighted in the micrograph, the fractured surface depicts three distinct features, namely, small alpha grains having equiaxed morphology, beta-SiAlON grains having elongated morphology, and relatively larger AlN polytype grains depicting a flat plate-like fractured morphology. Furthermore, in line with the phase-detection results, the alpha SiAlON is seen as the dominant phase, whereas fewer grains of beta SiAlON and AlN polytype are observed. Figure $3 \mathrm{~b}$ represents the high magnification image of the area highlighted in Figure 3a. The average grain size of the alpha phase is $290 \pm 76 \mathrm{~nm}$. It appears that the La-oxynitride eutectic liquid has facilitated the growth of minor phase(s) thereby restricting the development of the alpha phase.

For Nd-stabilized SiAlON (Figure 3c), in line with the X-ray diffraction results, the fractured surface is dominant with the equiaxed alpha SiAlON grain. At the same time, some elongated grains of beta-SiAlON (as highlighted in the image) are also observed. Again, as per FESEM observations, there were no visible signs of the amorphous glass phase at the grain boundaries. Figure $3 \mathrm{~d}$ represents the high magnification image of the area highlighted in Figure 3c. The average grain size of Nd-alpha SiAlON is measured to be $242 \pm 67 \mathrm{~nm}$. It is evident that unlike the case of La-stabilized SiAlONs, Nd-oxynitride eutectic liquid has promoted the formation of alpha SiAlON grains rather than the polytype AlN phase. 

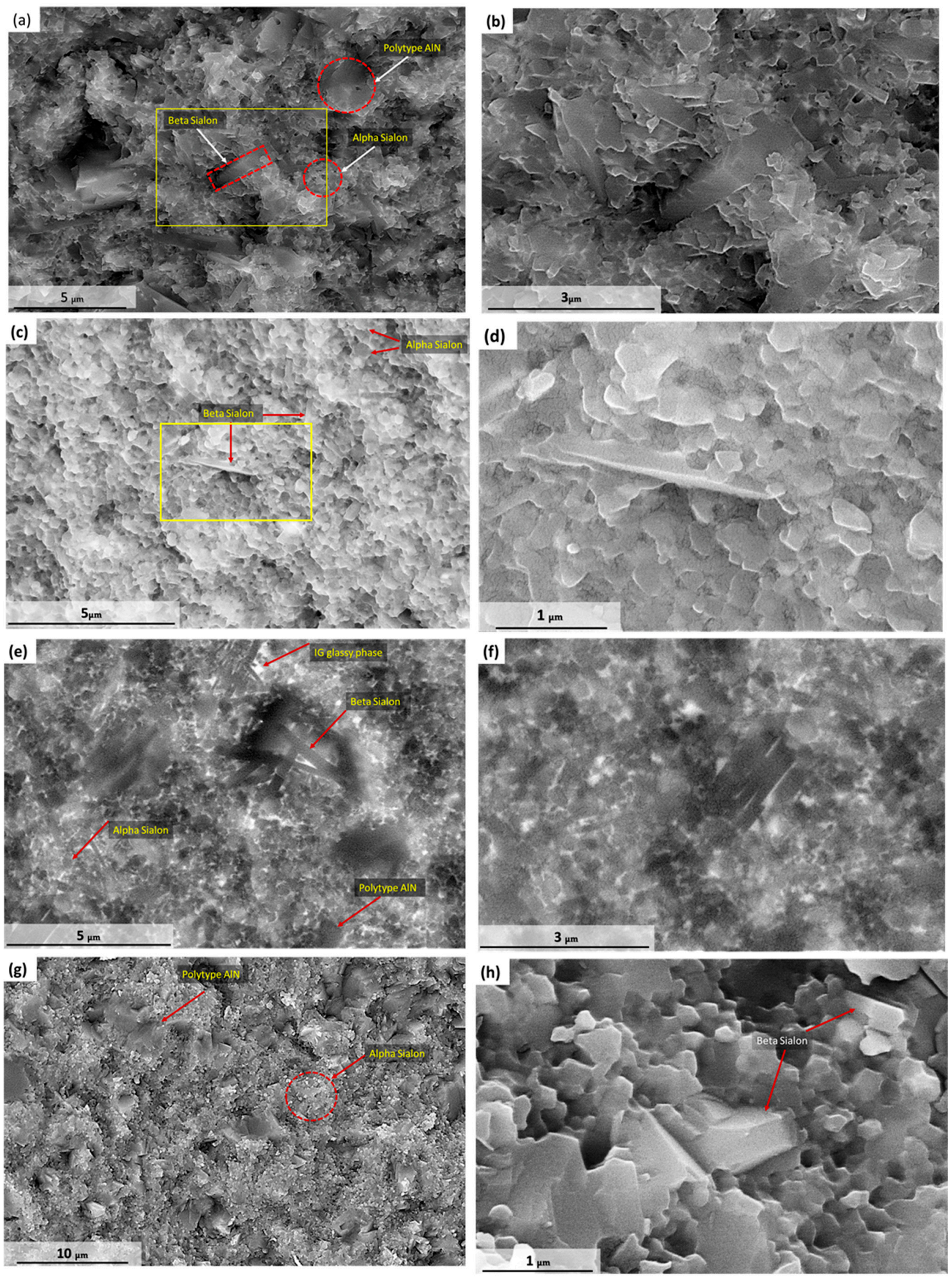

Figure 3. Cont. 

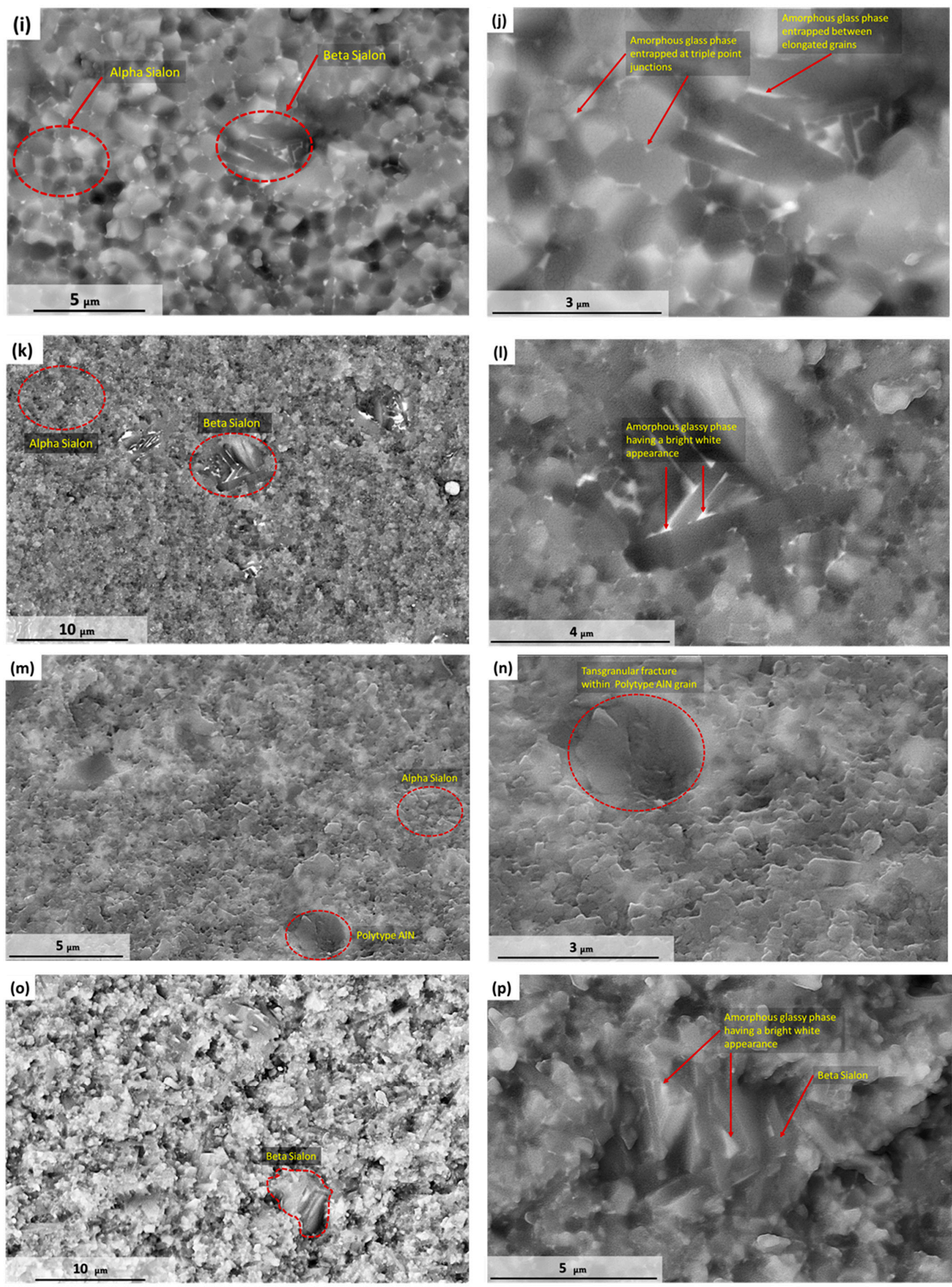

Figure 3. Cont. 


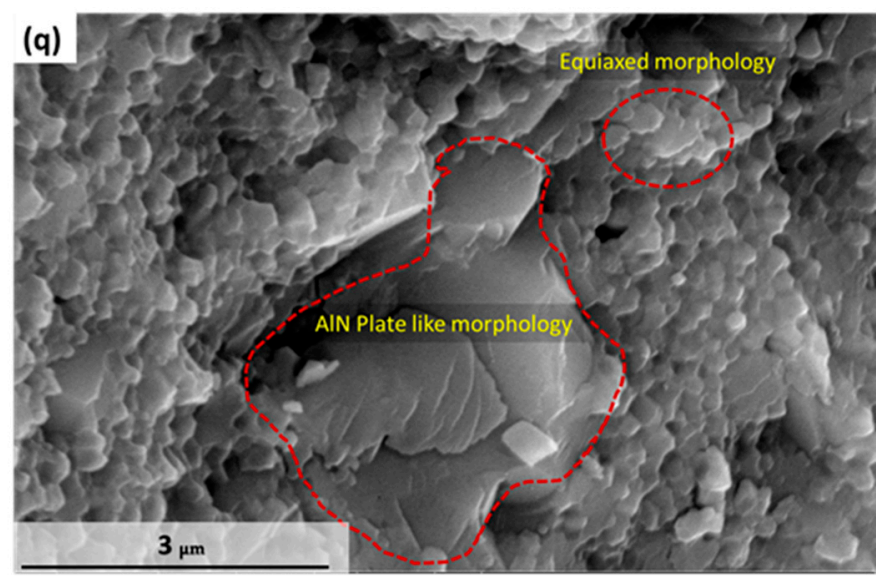

Figure 3. FESEM micrographs representing fractured surfaces of SiAlONs doped with (a,b) La, (c,d) Nd, (e,f) Eu, (g,h) Dy, $(\mathbf{i}, \mathbf{j}) \mathrm{Er},(\mathbf{k}, \mathbf{l}) \mathrm{Yb},(\mathbf{m}, \mathbf{n}) \mathrm{Ba},(\mathbf{o}, \mathbf{p}) \mathrm{Y}$, and $(\mathbf{q}) \mathrm{Mg}$, cations.

The distinct features as highlighted in the fractography of Eu-stabilized SiAlON (Figure 3e) include small equiaxed grains of alpha phase, elongated interlocking grains of beta phase, dark grey flat plate-like morphology of AlN polytype phase, and the bright white small pockets of intergranular (IG) amorphous glassy phase. Figure $3 \mathrm{f}$ represents the high magnification image acquired from a similar region. The average grain size of the alpha phase is $294 \pm 71 \mathrm{~nm}$. It is evident that much of the Eu-oxynitride eutectic liquid phase was present as the amorphous grain boundary phase and thereby growth of the well-developed alpha SiAlON phase was restricted.

The fractography of Dy-stabilized SiAlON (Figure 3g) depicts a mixed fracture surface where an equiaxed small alpha SiAlON grains area is surrounded by plate-like morphology of polytype AlN grains representing a transgranular fracture. The high magnification image (Figure $3 \mathrm{~h}$ ) of the same sample also indicates relatively thick fractured grains of beta SiAlONs with a relatively lower aspect ratio. However, any visible sign of the amorphous grain boundary phase is not present. The measured average alpha SiAlON grain size is $185 \pm 34 \mathrm{~nm}$.

The fractured surface of Er-stabilized SiAlON (Figure 3i) depicts well developed equiaxed morphology of alpha SiAlON as the dominant phase, along with pockets of beta-SiAlON phase having an elongated morphology. Furthermore, the presence of an intergranular glassy phase having a bright white appearance is also very evident. The high magnification image (Figure 3j) of the same sample further indicates that the amount of amorphous phase was minimal and is mainly present at triple point junctions and in between the elongated grains of beta SiAlON. The average alpha SiAlON grain size is measured to be $711 \pm 106 \mathrm{~nm}$.

In Yb-stabilized SiAlON (Figure 3k), the equiaxed morphology of alpha SiAlON phase is seen to be the dominant morphology whereas small regions having elongated morphology of beta SiAlON phase are also evident. The high magnification image (Figure 31) of the same sample provides the evidence of glassy phase present within the vicinity of interlocking elongated beta SiAlON grains. The appearance of the amorphous grain boundary phase is seen to be bright white in color as highlighted in Figure 31. The average size of alpha SiAlON grains is $538 \pm 109 \mathrm{~nm}$.

The general appearance of the fractured surface of Ba-stabilized SiAlON (Figure 3m) is dominant with equiaxed alpha SiAlON grains, while a few larger dark grey grains of AlN polytype phase are also observed. No evidence of glassy grain boundary phase is observed. The high magnification image (Figure $3 \mathrm{n}$ ) reveals a transgranular fracture mode within the polytype AlN grain. The measured average size of alpha SiAlON grains is $238 \pm 43 \mathrm{~nm}$.

The fracture surface of Y-stabilized SiAlON (Figure 3o) generally depicts the equiaxed appearance of alpha $\mathrm{SiAlON}$ grains, while small regions having elongated beta SiAlON morphology are also observed. The elongated morphology of the beta phase is more visible 
in the high magnification image (Figure 3p). An entrapped glassy phase in small amounts, having a brighter appearance, is also seen within the vicinity of elongated beta SiAlON grains. The average size of alpha SiAlON grains is measured to be $535 \pm 112 \mathrm{~nm}$.

The general appearance of the fractured surface of Mg-stabilized SiAlON (Figure 3q) is dominant with equiaxed alpha SiAlON grains while some larger dark grey grains of AlN polytype phase having a plate-like morphology are also observed. A transgranular fracture mode within the polytype AlN grain is quite evident, while no signs of the amorphous grain boundary phase are visible. The average size of alpha SiAlON grains is $277 \pm 50 \mathrm{~nm}$.

\subsection{Densification, Mechanical, and Thermal Properties}

The thermal and mechanical properties and the densities of spark-plasma-sintered SiAlON ceramic samples are listed in Table 3. Generally, it is observed that the density value has increased with the increase in the atomic number of charge stabilizing element (used as charge balance in the starting composition). This finding is in line with the previously reported work on SiAlON-based systems [61]. Any obvious sign of porosity has not been observed in the microscopic examination, which conforms with the comparatively good relative densification of the samples, specifically in reference to the relatively low sintering temperature of $1500{ }^{\circ} \mathrm{C}$. Although it is an established finding that high densification is associated with grain growth in the conventional sintering processing of SiAlON ceramics, in the present study grain growth was generally well controlled due to the much faster heating and cooling rates achieved via SPS. Unique and localized heating provided continuous dissolution and reaction of nanosized precursors in the oxynitride eutectic liquid, thereby playing a significant role in attaining near full densification at low temperature. Any direct relationship of thermal properties with the atomic size of charge stabilizers, as in the case of density, was not observed.

Table 3. Physical, mechanical, and thermal properties of Spark-Plasma-Sintered samples prepared at $1500{ }^{\circ} \mathrm{C}$.

\begin{tabular}{|c|c|c|c|c|c|c|c|c|c|}
\hline \multirow[b]{2}{*}{ Sample Id's } & \multicolumn{3}{|c|}{ Alkaline Earth Stabilizers } & \multicolumn{6}{|c|}{ Rare Earth Stabilizers } \\
\hline & Ba & Mg & $\mathbf{Y}$ & La & Nd & Eu & Dy & Er & $\mathbf{Y b}$ \\
\hline Density $\left(\mathrm{g} / \mathrm{cm}^{3}\right)$ & 3.42 & 3.17 & 3.23 & 3.47 & 3.53 & 3.59 & 3.67 & 3.78 & 3.92 \\
\hline Relative Density (\%) & 95 & 96 & 92 & 93 & 91 & 92 & 92 & 92 & 93 \\
\hline Thermal Conductivity (W/mK) & 6.04 & 6.80 & 6.49 & 6.13 & 6.09 & 6.04 & 5.79 & 6.91 & 6.67 \\
\hline Hardness Hv10 (GPa) & $12.4(5)$ & $16.9(4)$ & $15.5(4)$ & $16.6(5)$ & $16.2(6)$ & $16.3(4)$ & $17.0(6)$ & $15.1(4)$ & $15.6(5)$ \\
\hline Fracture Toughness $\mathrm{K}_{\mathrm{Ic}}\left(\mathrm{MPa} \cdot \mathrm{m}^{1 / 2}\right)$ & $4.1(4)$ & $4.4(6)$ & $5.1(5)$ & $4.5(7)$ & $4.3(2)$ & $4.5(2)$ & $4.2(2)$ & $5.7(7)$ & $6.2(6)$ \\
\hline
\end{tabular}

$( \pm)$ is represented by values in the curved brackets.

The thermal conductivity of SiAlONs has shown a mixed behavior where values were measured to be from 5.79 to $6.91 \mathrm{~W} / \mathrm{m} \cdot \mathrm{K}$. Generally, the thermal conductivity values are influenced by the grain size where Dy-doped SiAlON, having the smallest average grain size of $185 \mathrm{~nm}$, show the lowest thermal conductivity of $5.79 \mathrm{~W} / \mathrm{m} \cdot \mathrm{K}$; while Er-doped SiAlON, having the largest average grain size of $711 \mathrm{~nm}$, result in the highest thermal conductivity of $6.91 \mathrm{~W} / \mathrm{m} \cdot \mathrm{K}$. Huicong et al. reported that grain boundaries generally act as a hindrance in thermal transmission, thereby causing a decrease in thermal conductivity with decreasing grain size [67]. Since any significant variation in the thermal conductivity values has not been apparent, it is believed that other parameters such as porosity level and amount of minor phases have not had a significant role in influencing the thermal behavior of synthesized materials [19,68-70].

The measured hardness of all the samples is in the range of 12.4-17.0 GPa. Hakeem et al. reported hardness values in the range of 15.5-20.8 $\mathrm{GPa}\left(\mathrm{HV}_{10}\right)$ for nitrogen-rich alkaline-earth- and rare-earth-doped SiAlONs [61]. Relatively lower hardness values observed in the present study are ascribable to the initial composition selected for the synthesis, which belongs to the oxygen-rich region on the alpha SiAlON plane. Generally, the hardness of the SiAlON samples was found to be profoundly influenced by the alpha SiAlON grain size. In the rare earth series, it was observed that Dy-doped SiAlON, having the smallest average grain size of $185 \mathrm{~nm}$, has the highest hardness of $17.0 \mathrm{GPa}$. Er- and 
Yb-doped SiAlONs, having the average grain size values of $711 \mathrm{~nm}$ and $535 \mathrm{~nm}$, have relatively lower hardness values of 15.1 and $15.6 \mathrm{GPa}$, respectively. The presence of grain boundary liquid in Er- and $\mathrm{Yb}$-doped SiAlONs suggests that rare earth SiAlONs having the lowest ionic radius have not only promoted the formation of the eutectic liquid phase but have also favored the growth of alpha SiAlON grains. In the alkaline earth series, $\mathrm{Ba}-\mathrm{SiAlON}$ was measured to have the lowest hardness, primarily due to the presence of barium aluminosilicate phase in the matrix. The measured fracture toughness values of all the samples vary from 4.1 to $6.2 \mathrm{MPa} \cdot \mathrm{m}^{1 / 2}$. It is seen that a higher ionic radius promotes the formation of AlN polytype phase which ultimately lowers the fracture toughness of the samples. Biswas et al. reported AlN fracture toughness values in the range of 2.4-3.9 MPa $\mathrm{m}^{1 / 2}$ [71], which supports the lower fracture toughness values observed in the present work. Furthermore, Er- and Yb-doped SiAlONs having well developed beta SiAlON regions and entrapped grain boundary phases are found to have the highest fracture toughness values of 5.7 and $6.2 \mathrm{MPa} \cdot \mathrm{m}^{1 / 2}$, respectively. Plastic deformation of the secondary phase crystals and the grain boundaries are reported to be prominent reasons for improved fracture toughness $[6,13,14,28,68,72-74]$. It is further reported in the literature that cracks will be inclined to propagate along the grain boundary interface when the secondary phase grains or grain boundary glassy region is well connected to the matrix grains $[13,28,68]$. With the results of the present work, very well suited SiAlON ceramics could be developed for the drilling and cutting tools industry. In today's competitive world, it is highly desirable to have an economically viable manufacturing route. In comparison with the already published literature, it is apparent that well suited SiAlON-based cutting tools can be developed economically via non-traditional sintering techniques (such as SPS) at considerably lower sintering temperatures.

\section{Conclusions}

Metal-oxide-stabilized SiAlON ceramics having the $m$ value of 1.1 and $n$ value of 1.6 were synthesized at the sintering temperature of $1500^{\circ} \mathrm{C}$. Thoroughly densified SiAlON ceramics having values in between $3.17-3.92 \mathrm{~g} / \mathrm{cm}^{3}$ were developed by employing a nanosized starting powder mixture coupled with the unique and efficient heating mechanism provided by spark plasma sintering. The thermal conductivity values were found to vary in the narrow range of $5.79-6.91 \mathrm{~W} / \mathrm{m} \cdot \mathrm{K}$, where the Er-stabilized sample had the highest value owing to its largest grain size. The hardness and fracture toughness values were measured to be in the range of 12.4-17.0 GPa and 4.1-6.2 MPa $\mathrm{m}^{1 / 2}$, respectively. The high fracture toughness of Er- and $\mathrm{Yb}$-doped SiAlON was attributed to the presence of elongated beta SiAlON grains in the alpha matrix. It is concluded that SiAlON ceramics stabilized with various charge stabilizers having diversified thermal and mechanical properties could be utilized for products requiring high contact resistance such as bearings, cutting tools, and automotive brake pads.

Author Contributions: Conceptualization, B.A.A., A.S.H.; Data curation, M.Z.F. and S.U.B.; Formal analysis, B.A.A. and H.A.S.; Investigation, M.Z.F., B.A.A., A.S.H. and U.A.A.; Methodology, M.Z.F., B.A.A., S.U.B. and A.S.H.; Project administration, B.A.A. and H.A.S.; Resources, A.S.H. and U.A.A.; Supervision, B.A.A., H.A.S. and S.U.B.; Writing—original draft, M.Z.F. and B.A.A.; Writing—review \& editing, B.A.A., H.A.S., S.U.B., A.S.H. and U.A.A. All authors have read and agreed to the published version of the manuscript.

Funding: This research received no external funding.

Institutional Review Board Statement: Not applicable.

Informed Consent Statement: Not applicable.

Data Availability Statement: Not applicable.

Conflicts of Interest: The authors declare no conflict of interest. 


\section{References}

1. Jack, K.H. Nitrogen Ceramics for Engine Applications. Mater. Sci. Forum 2000, 325, 255-264. [CrossRef]

2. Jack, K.H. Prospects for Nitrogen Ceramics. Key Eng. Mater. 1994, 89-91, 345-350. [CrossRef]

3. Jack, K.H. Sialons and related nitrogen ceramics. J. Mater. Sci. 1976, 11, 1135-1158. [CrossRef]

4. Lewis, M.H. Sialons and silicon nitrides; microstructural design and performance. MRS Proc. 1993, 287, 159-172. [CrossRef]

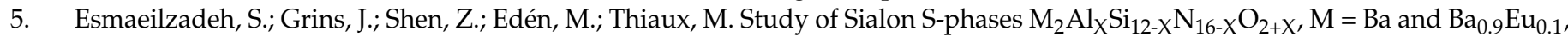
by $\mathrm{x}$-ray single crystal diffraction, X-ray powder diffraction, and solid-state nuclear magnetic resonance. Chem. Mater. 2004, 16, 2113-2120. [CrossRef]

6. Santos, C.; Strecker, K.; Ribeiro, S.; Souza, J.V.; Silva, O.; Silva, C. $\alpha$-SiAlON ceramics with elongated grain morphology using an alternative sintering additive. Mater. Lett. 2004, 58, 1792-1796. [CrossRef]

7. Becher, P.F.; Waters, S.B.; Westmoreland, C.G.; Riester, L. Compositional Effects on the Properties of Si-Al-RE-Based Oxynitride Glasses (RE = La, Nd, Gd, Y, or Lu). J. Am. Ceram. Soc. 2002, 85, 897-902. [CrossRef]

8. Cao, G.Z.; Metselaar, R. .alpha.'-Sialon ceramics: A review. Chem. Mater. 1991, 3, 242-252. [CrossRef]

9. Ahmed, B.A.; Laoui, T.; Hakeem, A.S. Development of calcium stabilized nitrogen rich $\alpha$-sialon ceramics along the Si3N4:1/2Ca3N2:3AlN line using spark plasma sintering. J. Adv. Ceram. 2020, 9, 606-616. [CrossRef]

10. Hampshire, S. Oxynitride glasses, their properties and crystallization-A review. J. Non Cryst. Solids 2003, 316, 64-73. [CrossRef]

11. Al Malki, M.M.; Khan, R.M.A.; Hakeem, A.S.; Hampshire, S.; Laoui, T. Effect of Al metal precursor on the phase formation and mechanical properties of fine-grained SiAlON ceramics prepared by spark plasma sintering. J. Eur. Ceram. Soc. 2017, 37, 1975-1983. [CrossRef]

12. Ahmed, B.A.; Hakeem, A.; Laoui, T. Effect of nano-size oxy-nitride starting precursors on spark plasma sintering of calcium sialons along the alpha/(alpha + beta) phase boundary. Ceram. Int. 2019, 45, 9638-9645. [CrossRef]

13. Ahmed, B.A.; Hakeem, A.S.; Laoui, T.; Al Malki, M.; Ehsan, M.A.; Ali, S. Low-temperature spark plasma sintering of calcium stabilized alpha sialon using nano-size aluminum nitride precursor. Int. J. Refract. Met. Hard Mater. 2018, 71, 301-306. [CrossRef]

14. Khan, R.M.A.; Ahmed, B.A.; Al Malki, M.M.; Hakeem, A.S.; Laoui, T. Synthesis of hard and tough calcium stabilized $\alpha$-sialon/SiC ceramic composites using nano-sized precursors and spark plasma sintering. J. Alloys Compd. 2018, 757, 200-208. [CrossRef]

15. Angerer, P.; Yu, L.; Khor, K.; Korb, G.; Zalite, I. Spark-plasma-sintering (SPS) of nanostructured titanium carbonitride powders. J. Eur. Ceram. Soc. 2005, 25, 1919-1927. [CrossRef]

16. Hakeem, A.S.; Laoui, T.; Ehsan, M.A.; Ahmed, B.A. Spark Plasma Method for Making cBN/SiAlON Ceramics. U.S. Patent 10,550,042,B2, 4 February 2020.

17. Ye, F.; Iwasa, M.; Su, C.; Chen, S. Self-reinforced Y- $\alpha$-sialon ceramics with barium.aluminosilicate as an additive. J. Mater. Res. 2003, 18, 2446-2450. [CrossRef]

18. Hakeem, A.S.; Laoui, T.; Irshad, H.M.; Ahmed, B.A.; Ehsan, M.A. Method for Making an $\mathrm{Al}_{2} \mathrm{O}_{3}-\mathrm{cBN}_{\mathrm{BN}} \mathrm{Composite}$ U.S. Patent 10,858,292,B2, 8 December 2020.

19. Hakeem, A.S.; Laoui, T.; Almaliki, M.M.; Khan, A.M.R.; Patel, F. Method for Forming Sintered Ceramic Material. U.S. Patent 10,364,192B2, 30 July 2019.

20. Wood, C.A.; Zhao, H.; Cheng, Y.-B. Microstructural Development of Calcium alpha-SiAlON Ceramics with Elongated Grains. J. Am. Ceram. Soc. 1999, 82, 421-428. [CrossRef]

21. Shin, I.; Kim, D.J. Growth of elongated grains in $\alpha$-SiAlON ceramics. Mater. Lett. 2001, 47, 329-333. [CrossRef]

22. Nguyen, T.P.; Kakroudi, M.G.; Asl, M.S.; Ahmadi, Z.; Namini, A.S.; Delbari, S.A.; Van Le, Q.; Shokouhimehr, M. Influence of SiAlON addition on the microstructure development of hot-pressed $\mathrm{ZrB}_{2}-\mathrm{SiC}$ composites. Ceram. Int. 2020, 46, 19209-19216. [CrossRef]

23. Asl, M.S.; Nayebi, B.; Ahmadi, Z.; Pirmohammadi, P.; Kakroudi, M.G. Fractographical characterization of hot pressed and pressureless sintered SiAlON-doped ZrB2-SiC composites. Mater. Charact. 2015, 102, 137-145. [CrossRef]

24. Guillon, O.; Gonzalez-Julian, J.; Dargatz, B.; Kessel, T.; Schierning, G.; Räthel, J.; Herrmann, M. Field-Assisted Sintering Technology/Spark Plasma Sintering: Mechanisms, Materials, and Technology Developments. Adv. Eng. Mater. 2014, 16, 830-849. [CrossRef]

25. Guo, Z.; Blugan, G.; Kirchner, R.; Reece, M.; Graule, T.; Kuebler, J. Microstructure and electrical properties of $\mathrm{Si}_{3} \mathrm{~N}_{4}-\mathrm{TiN}$ composites sintered by hot pressing and spark plasma sintering. Ceram. Int. 2007, 33, 1223-1229. [CrossRef]

26. Saheb, N.; Iqbal, Z.; Khalil, A.; Hakeem, A.S.; Al-Aqeeli, N.; Laoui, T.; Al-Qutub, A.; Kirchner, R. Spark Plasma Sintering of Metals and Metal Matrix Nanocomposites: A Review. J. Nanomater. 2012, 2012, 983470. [CrossRef]

27. Ahmed, B.A.; Ahmed, F.; Hakeem, A.S. Joule Heating in Two-dimensional Materials Based Transistors. Res. Dev. Mater. Sci. 2019, 10. [CrossRef]

28. Adeniyi, A.S.; Ahmed, B.A.; Hakeem, A.S.; Patel, F.; Bakare, A.I.; Ul-Hamid, A.; Khan, A.A.; Ehsan, M.A.; Khan, T.I. The Property Characterization of $\alpha$-Sialon/Ni Composites Synthesized by Spark Plasma Sintering. Nanomaterials 2019, 9, 1682. [CrossRef]

29. Peng, G.-H.; Li, X.-G.; Liang, M.; Liang, Z.-H.; Liu, Q.; Li, W.-L. Spark plasma sintered high hardness $\alpha / \beta \mathrm{Si}_{3} \mathrm{~N}_{4}$ composites with $\mathrm{MgSiN}_{2}$ as additives. Scr. Mater. 2009, 61,347-350. [CrossRef]

30. Belmonte, M.; Gonzalez-Julian, J.; Miranzo, P.; Osendi, M.I. Spark plasma sintering: A powerful tool to develop new silicon nitride-based materials. J. Eur. Ceram. Soc. 2010, 30, 2937-2946. [CrossRef] 
31. Cai, Y.; Shen, Z.; Höche, T.; Grins, J.; Esmaeilzadeh, S. Superplastic deformation of nitrogen-rich Ca- $\alpha$-sialon ceramics. Mater. Sci. Eng. A 2008, 475, 81-86. [CrossRef]

32. Al Wohaibi, S.; Mohammed, A.S.; Laoui, T.; Hakeem, A.S.; Adesina, A.Y.; Patel, F. Tribological Characterization of Micron-/NanoSized WC-9\%Co Cemented Carbides Prepared by Spark Plasma Sintering at Elevated Temperatures. Materials 2019, 12, 920. [CrossRef]

33. Ahmadi, Z.; Zakeri, M.; Farvizi, M.; Habibi-Yangjeh, A.; Asadzadeh-Khaneghah, S.; Asl, M.S. Synergistic influence of SiC and $\mathrm{C}_{3} \mathrm{~N}_{4}$ reinforcements on the characteristics of $\mathrm{ZrB}_{2}$-based composites. J. Asian Ceram. Soc. 2021, 9, 53-62. [CrossRef]

34. Pazhouhanfar, Y.; Delbari, S.A.; Asl, M.S.; Shaddel, S.; Pazhouhanfar, M.; Van Le, Q.; Shokouhimehr, M.; Mohammadi, M.; Namini, A.S. Characterization of spark plasma sintered TiC-Si $\mathrm{N}_{4}$ ceramics. Int. J. Refract. Met. Hard Mater. 2020, 95, 105444. [CrossRef]

35. Nguyen, V.-H.; Delbari, S.A.; Asl, M.S.; Van Le, Q.; Jang, H.W.; Shokouhimehr, M.; Mohammadi, M.; Namini, A.S. A novel spark plasma sintered TiC-ZrN-C composite with enhanced flexural strength. Ceram. Int. 2020, 46, 29022-29032. [CrossRef]

36. Nguyen, T.P.; Mahaseni, Z.H.; Germi, M.D.; Delbari, S.A.; Van Le, Q.; Ahmadi, Z.; Shokouhimehr, M.; Asl, M.S.; Namini, A.S Densification behavior and microstructure development in TiB2 ceramics doped with h-BN. Ceram. Int. 2020, 46, 18970-18975. [CrossRef]

37. Fattahi, M.; Asl, M.S.; Delbari, S.A.; Namini, A.S.; Ahmadi, Z.; Mohammadi, M. Role of nano-WC addition on microstructural, mechanical and thermal characteristics of TiC-SiCw composites. Int. J. Refract. Met. Hard Mater. 2020, 90, 105248. [CrossRef]

38. Hussein, M.A.; Shahzad, H.K.; Patel, F.; Atieh, M.A.; Al-Aqeeli, N.; Baroud, T.N.; Laoui, T. Porous $\mathrm{Al}_{2} \mathrm{O}_{3}-\mathrm{CNT}_{\mathrm{Nanocomposite}}$ Membrane Produced by Spark Plasma Sintering with Tailored Microstructure and Properties for Water Treatment. Nanomaterials 2020, 10, 845. [CrossRef]

39. Mohamedkhair, A.; Hakeem, A.; Drmosh, Q.; Mohammed, A.; Baig, M.; Ul-Hamid, A.; Gondal, M.; Yamani, Z. Fabrication and Characterization of Transparent and Scratch-Proof Yttrium/Sialon Thin Films. Nanomaterials 2020, 10, 2283. [CrossRef]

40. Oeckler, O.; Kechele, J.A.; Koss, H.; Schmidt, P.J.; Schnick, W. $\mathrm{Sr}_{5} \mathrm{Al}_{5+\chi} \mathrm{Si}_{21-\chi} \mathrm{N}_{35-\chi} \mathrm{O}_{2+\chi}: \mathrm{Eu}^{2+}(\mathrm{x} \approx 0)$-A Novel Green Phosphor for White-Light pcLEDs with Disordered Intergrowth Structure. Chem. Eur. J. 2009, 15, 5311-5319. [CrossRef] [PubMed]

41. Garrett, J.; Sigalas, I.; Wolfrum, A.; Herrmann, M. Effect of cubic boron nitride grain size in the reinforcing of $\alpha$-Sialon ceramics sintered via SPS. J. Eur. Ceram. Soc. 2015, 35, 451-462. [CrossRef]

42. Li, J.; Yin, R. Advanced Functional Materials; Springer: Singapore, 2018.

43. Zhong, J.; Gao, H.; Yuan, Y.; Chen, L.; Chen, D.; Ji, Z. Eu ${ }^{3+}$-doped double perovskite-based phosphor-in-glass color converter for high-power warm w-LEDs. J. Alloys Compd. 2018, 735, 2303-2310. [CrossRef]

44. Hakeem, A.S.; Ali, S.; Jonson, B. Preparation and properties of mixed La-Pr silicate oxynitride glasses. J. Non Cryst. Solids 2013, 368, 93-97. [CrossRef]

45. Hakeem, A.S.; Daucé, R.; Leonova, E.; Edén, M.; Shen, Z.; Grins, J.; Esmaeilzadeh, S. Silicate Glasses with Unprecedented High Nitrogen and Electropositive Metal Contents Obtained by Using Metals as Precursors. Adv. Mater. 2005, 17, 2214-2216. [CrossRef]

46. Santos, C.; Strecker, K.; Baldacim, S.; Silva, O.; Silva, C. Properties of hot-pressed, partially stabilized CRE- $\alpha$-SiAlONs as a function of the additive content. Int. J. Refract. Met. Hard Mater. 2004, 22, 79-85. [CrossRef]

47. Tanaka, I.; Kleebe, H.-J.; Cinibulk, M.K.; Bruley, J.; Clarke, D.R.; Ruhle, M. Calcium Concentration Dependence of the Intergranular Film Thickness in Silicon Nitride. J. Am. Ceram. Soc. 1994, 77, 911-914. [CrossRef]

48. Huang, Z.-K.; Tien, T.-Y. Solid-Liquid Reaction in the $\mathrm{Si}_{3} \mathrm{~N}_{4}-\mathrm{AlN}-\mathrm{Y}_{2} \mathrm{O}_{3}$ System under $1 \mathrm{MPa}$ of Nitrogen. J. Am. Ceram. Soc. 1996, 79, 1717-1719. [CrossRef]

49. Joshi, B.; Gyawali, G.; Wang, H.; Sekino, T.; Lee, S.W. Thermal and mechanical properties of hot pressed translucent $\mathrm{Y} 2 \mathrm{O} 3$ doped $\mathrm{Mg}-\alpha / \beta$-Sialon ceramics. J. Alloys Compd. 2013, 557, 112-119. [CrossRef]

50. Çalışkan, F.; Tatli, Z.; Genson, A.; Hampshire, S. Pressureless sintering of $\beta$-SiAlON ceramic compositions using fluorine and oxide additive system. J. Eur. Ceram. Soc. 2012, 32, 1337-1342. [CrossRef]

51. Yin, L.; Xu, Y.; Huang, Z.; Liu, Y.-G.; Fang, M.; Liu, B. Synthesis of $\mathrm{ZrN}-\mathrm{Si}_{3} \mathrm{~N}_{4}$ composite powders from zircon and quartz by carbothermal reduction and nitridation. Powder Technol. 2013, 246, 677-681. [CrossRef]

52. Santos, C.; Kelly, C.; Ribeiro, S.; Strecker, K.; Souza, J.; Silva, O. $\alpha$-SiAlON-SiC composites obtained by gas-pressure sintering and hot-pressing. J. Mater. Process. Technol. 2007, 189, 138-142. [CrossRef]

53. Cai, Y.; Shen, Z.; Grins, J.; Esmaeilzadeh, S. Sialon Ceramics Prepared by Using $\mathrm{CaH}_{2}$ as a Sintering Additive. J. Am. Ceram. Soc. 2008, 91, 2997-3004. [CrossRef]

54. Yi, X.; Niu, J.; Akiyama, T.; Harada, K.; Nakatsugawa, I. Spark plasma sintering behavior of combustion-synthesized (Y, Ca)- $\alpha$-SiAlON. Ceram. Int. 2016, 42, 15687-15693. [CrossRef]

55. Xiong, Y.; Fu, Z.; Wang, H.; Wang, Y.; Zhang, J.; Zhang, Q. Microstructure and properties of translucent Mg-sialon ceramics prepared by spark plasma sintering. Mater. Sci. Eng. A 2008, 488, 475-481. [CrossRef]

56. Jojo, N.; Shongwe, M.B.; Tshabalala, L.C.; Olubambi, P.A. Effect of Sintering Temperature and Yttrium Composition on the Densification, Microstructure and Mechanical Properties of Spark Plasma Sintered Silicon Nitride Ceramics with $\mathrm{Al}_{2} \mathrm{O}_{3}$ and $\mathrm{Y}_{2} \mathrm{O}_{3}$ Additives. Silicon 2019, 11, 2689-2699. [CrossRef]

57. Ye, F.; Zhang, L.; Zhang, H.; Liu, L.; Liu, C.; Zhou, Y. Rapid densification and reaction sequences in self-reinforced Y- $\alpha$-SiAlON ceramics with barium aluminosilicate as an additive. Mater. Sci. Eng. A 2009, 527, 287-291. [CrossRef] 
58. Wang, P.; Zhang, C.; Sun, W.; Yan, D. Formation behavior of multi-cation $\alpha$-sialons containing calcium and magnesium. Mater. Lett. 1999, 38, 178-185. [CrossRef]

59. Nino, A.; Sasago, A.; Sugiyama, S.; Taimatsu, H. Preparation of $\mathrm{Si}_{3} \mathrm{~N}_{4}-\mathrm{TaC}$ and $\mathrm{Si}_{3} \mathrm{~N}_{4}-\mathrm{ZrC}$ composite ceramics and their mechanical properties. Int. J. Refract. Met. Hard Mater. 2016, 61, 192-200. [CrossRef]

60. Ekström, T.; Nygren, M. SiAION Ceramics. J. Am. Ceram. Soc. 1992, 75, 259-276. [CrossRef]

61. Hakeem, A.S.; Khan, M.; Ahmed, B.A.; Al Ghanim, A.; Patel, F.; Ehsan, M.A.; Ali, S.; Laoui, T.; Ali, S. Synthesis and characterization of alkaline earth and rare earth doped sialon Ceramics by spark plasma sintering. Int. J. Refract. Met. Hard Mater. 2021, 97, 105500. [CrossRef]

62. Lee, C.-H.; Liu, H.-C.; Lu, H.-H.; Goto, T.; Tu, R.; Wang, C.-A.; Pavol, S.; Ruan, J.-L.; Nayak, P.K.; Chen, J.-H.; et al. Indentation Deformation and Microcracking in $\beta-\mathrm{Si}_{3} \mathrm{~N}_{4}$-Based Nanoceramic. J. Am. Ceram. Soc. 2012, 95, 1421-1428. [CrossRef]

63. Souza, J.V.C.; Santos, C.; Kelly, C.; Silva, O. Development of $\alpha$-SiAlON-SiC ceramic composites by liquid phase sintering. Int. J. Refract. Met. Hard Mater. 2007, 25, 77-81. [CrossRef]

64. Khan, R.M.A.; Al Malki, M.M.; Hakeem, A.S.; Ehsan, M.A.; Laoui, T. Development of a single-phase Ca- $\alpha$-SiAlON ceramic from nanosized precursors using spark plasma sintering. Mater. Sci. Eng. A 2016, 673, 243-249. [CrossRef]

65. Evans, A.G.; Charles, E.A. Fracture Toughness Determinations by Indentation. J. Am. Ceram. Soc. 1976, 59, 371-372. [CrossRef]

66. Hakeem, A.S.; Grins, J.; Esmaeilzadeh, S. La-Si-O-N glasses: Part I. Extension of the glass forming region. J. Eur. Ceram. Soc. 2007, 27, 4773-4781. [CrossRef]

67. Dong, H.; Wen, B.; Melnik, R. Relative importance of grain boundaries and size effects in thermal conductivity of nanocrystalline materials. Sci. Rep. 2014, 4, 7037. [CrossRef]

68. Irshad, H.M.; Ahmed, B.A.; Ehsan, M.A.; Khan, T.I.; Laoui, T.; Yousaf, M.R.; Ibrahim, A.; Hakeem, A.S. Investigation of the structural and mechanical properties of micro-/nano-sized $\mathrm{Al}_{2} \mathrm{O}_{3}$ and cBN composites prepared by spark plasma sintering. Ceram. Int. 2017, 43, 10645-10653. [CrossRef]

69. Ali, S.; Ahmed, B.A.; Irshad, H.M.; Bakare, A.I.; Hakeem, A.S.; Qamaruddin, M.; Ehsan, M.A.; Ali, S.; Azam, M.U. Evaluation of alumina reinforced oil fly ash composites prepared by spark plasma sintering. Int. J. Appl. Ceram. Technol. 2020, 17, $1948-1958$. [CrossRef]

70. Azam, M.U.; Ahmed, B.A.; Hakeem, A.S.; Irshad, H.M.; Laoui, T.; Ehsan, M.A.; Patel, F.; Khalid, F.A. Tribological behaviour of alumina-based nanocomposites reinforced with uncoated and Ni-coated cubic boron nitride. J. Mater. Res. Technol. 2019, 8 , 5066-5079. [CrossRef]

71. Biswas, M.; Bandyopadhyay, S. 27R-SiAlON Reinforced AlN Composite: Synthesis, Sintering and Characterization. Met. Mater. Int. 2021, 27, 1779-1789. [CrossRef]

72. Anstis, G.; Chantikul, P.; Lawn, B.; Marshall, D. A Critical Evaluation of Indentation Techniques for Measuring Fracture Toughness: I, Direct Crack Measurements. J. Am. Ceram. Soc. 1981, 64, 533-538. [CrossRef]

73. Quinn, G.D.; Salem, J.; Baron, I.; Cho, K.; Foley, M.; Fang, H. Fracture toughness of advanced ceramics at room temperature. J. Res. Natl. Inst. Stand. Technol. 1992, 97, 579-607. [CrossRef]

74. Gong, J.; Wu, J.; Guan, Z. Examination of the indentation size effect in low-load vickers hardness testing of ceramics. J. Eur. Ceram. Soc. 1999, 19, 2625-2631. [CrossRef] 